\title{
Hemolymph cell types of the mussel Mytilus galloprovincialis
}

\author{
María J. Carballal ${ }^{1}$, M. Carmen López ${ }^{1}$, Carlos Azevedo ${ }^{2}$, Antonio Villalba ${ }^{1}$

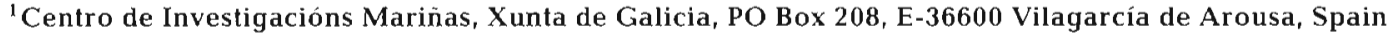 \\ ${ }^{2}$ Deparment of Cell Biology, Institute of Biomedical Sciences, University of Oporto, P-4000 Porto, Portugal
}

\begin{abstract}
Two types of circulating hemocytes were identified in Mytilus galloprovincialis hemolymph: hyalinocytes and granulocytes. The hyalinocytes are agranular cells and show a central nucleus surrounded by relatively small cytoplasm. The granulocytes are larger than hyalinocytes and have smaller nuclei. Three classes of granulocytes (acidophilic granulocytes, basophilic granulocytes and granulocytes containing both types of granules) were distinguished based on staining properties of their cytoplasmic granules. At the ultrastructural level, the hyalinocytes show characteristics of undifferentiated cells. The granulocytes are more differentiated and have membrane-limited cytoplasmic granules. Some granulocytes contain only small granules; others have numerous large granules and some of them contain a mix of granule sizes. Density gradient centrifugation allowed the separation of acidophilic granulocytes from the other types. Immunocharacterization demonstrated that the granulocytes are an antigenically heterogeneous population.
\end{abstract}

KEY WORDS: Mytilus galloprovincialis Hemocyte types Hemolymph - Isopycnic centrifugation Monoclonal antibodies

\section{INTRODUCTION}

Bivalve hemolymph cells develop a number of functions including wound and shell repair, transport and digestion of nutrients, and internal defence (Cheng 1981, 1984, Fisher 1986). In order to understand these functions, it is important to distinguish the hemocyte populations and subpopulations and to characterize them. Two basic cell types are recognized among bivalve hemocytes (reviewed by Cheng 1981, Auffret 1988): agranular (hyalinocytes) and granular (granulocytes). Both hemocyte types were observed in every studied species except in Pectinidae, which lack granulocytes (Auffret 1988). Recently, other hemocyte types were identified in Cerastoderma edule (RussellPinto et al. 1994) and Scapharca inaequivalvis (Holden et al. 1994). In addition, hemocyte subpopulations whose role is unknown were found.

Morphological criteria were considered to be insufficient to characterize mollusc hemocyte types. Therefore, several authors have used other criteria such as the enzyme content (Moore \& Lowe 1977, Bayne et al. 1979, Pipe 1990a), antigenic characterization (Yoshino
\& Granath 1983, 1985, Dikkeboom et al. 1985, 1988, Morvan 1991, Noël et al. 1994) or lectin-related properties (Pipe 1990b). Cell separation techniques have also been applied to obtain pure or enriched fractions of hemocyte populations and subpopulations such as isopycnic centrifugation in a discontinuous density gradient (Cheng et al. 1980, Bachere et al. 1988, Renwrantz 1990, Noël et al. 1993, Adema 1994, Ford et al. 1994) and the use of monoclonal antibodies bound to magnetic beads (Morvan 1991).

Studies on mussel (mostly Mytilus edulis) hemocyte types have been carried out by several authors (Feng et al. 1977. Moore \& Lowe 1977. Bayne et al. 1979, Rasmussen et al. 1985, Pipe 1990a, Renwrantz 1990, Noël et al. 1994), but there is no study on Mytilus galloprovincialis hemocytes. Whether the differences between $M$. edulis and $M$. galloprovincialis are sufficiently large to warrant full species status for each is a controversial matter. M. galloprovincialis is considered to be a true species by some authors (Sanjuán et al. 1990, 1994, Koëhn 1991, McDonald et al. 1991) and as the subspecies Mytilus edulis galloprovincialis by others (Gardner 1992, Gosling 1992). Regardless of their 
taxonomic rank, each taxon is adapted to different environmental conditions, thus explaining their different geographical distribution.

Recent findings point out that, in spite of widespread hybridization between Mytilus edulis and M. galloprovincialis in some areas, each taxon maintains its genetic identity in those areas (Gardner 1995, 1996). As a matter of fact, in hybrid populations (where representatives of each pure taxa and hybrids coexist) fitness advantages for $M$. galloprovincialis were found, such as higher strength of attachment to the substrate (Gardner \& Skibinski 1991, Willis \& Skibinski 1992), greater fecundity (Gardner \& Skibinski 1990), greater viability (Gardner et al. 1993), and non-susceptibility to the parasitic trematode Prosorrhynchus squamatus (Cousteau et al. 1991). In addition, Hilbish et al. (1994) pointed out that differences in a few genes could be responsible for the significant differences observed in energetic physiology between both taxa.

Evidence from studies on the fine structure of the spermatozoon (Crespo et al. 1990), allozymic loci (Sanjuán et al. 1994, Quesada et al. 1995), karyotype (Martínez-Lage et al. 1992) and mitochondrial DNA (Sanjuán et al.1996) indicates that the mussel of Galicia corresponds to the Mytilus galloprovincialis taxon.

Since it was not known if hemocytes of both mussel taxa have different characteristics, the aim of this study was to characterize the circulating hemocytes of Galician mussels, as a preliminary step towards understanding their defence mechanisms. To this purpose morphological, antigenic, and differential density criteria were used.

\section{MATERIALS AND METHODS}

Mussels (shell length 7 to $10 \mathrm{~cm}$ ) were collected from a culture raft in the Ría de Arosa (Galicia, NW Spain) and placed in a circulating seawater system in the laboratory until the next day. Hemolymph was obtained from the posterior adductor muscle sinus with sterile hypodermic needles (23 G) and $2 \mathrm{ml}$ syringes.

Hemocyte slides. Monolayers of hemocytes were prepared by allowing cells to settle onto glass slides (spontaneous monolayers) or by adhesion of cells to glass slides using a cytocentrifuge (cytospin smears). In order to prepare spontaneous monolayers, hemolymph was withdrawn directly (1:4) in filtered seawater (FSW, $0.22 \mu \mathrm{m}$ ). A drop of this suspension was deposited on clean slides and kept in a wet chamber for $30 \mathrm{~min}$. After washing in FSW, momolayers were fixed for $5 \mathrm{~min}$ in $1.25 \%$ glutaraldehyde in $0.01 \mathrm{M}$ phosphate buffer and stained with May-Grünwald-Giemsa (Auffret 1989). Monolayers from 10 mussels were made. In order to prepare cytospin smears, hemolymph was withdrawn and simultaneously diluted $1: 3$ in antiaggregant modified Alsever's solution (glucose: $20.8 \mathrm{~g}$; sodium citrate: $8 \mathrm{~g}$; EDTA: $3.36 \mathrm{~g}$; $\mathrm{NaCl}: 22.3 \mathrm{~g}_{;} \mathrm{H}_{2} \mathrm{O}$ : $1000 \mathrm{ml}$ ) (Bachère et al. 1988). The number of hemocytes in the suspension was estimated in a Malassez hemocytometer. Then, a volume of the suspension containing $3 \times 10^{4}$ cells was centrifuged $\left(92 \times g, 5 \mathrm{~min}, 4^{\circ} \mathrm{C}\right)$ using a Megafuge $1.0 \mathrm{R}$ (Heraeus) cytocentrifuge. Hemocytes were subsequently fixed and stained with a Hemacolor kit (Merck). Cytospin smears of 540 mussels (monthly samples of 30 mussels throughout an 18 mo period) were prepared, since they were used also to determine seasonal variability and the influence of other factors on the hemogram (published elsewhere).

Hemocyte measurements. Hemocyte dimensions were estimated in a spontaneous monolayer. A total of 174 stained cells were measured under light microscopy using an ocular micrometer. Cell size was determined by measuring the longest axis excluding pseudopodia. Nuclear size was estimated by measuring the longest nuclear diameter.

Dimensions of cells, fixed in suspension, were also determined. For this purpose, the hemolymph was withdrawn directly $(1: 1)$ in a Alsever's solution containing $6 \%$ formalin to avoid hemocyte degranulation. Hemolymph from 3 mussels was pooled. Hemocytes were fixed for $15 \mathrm{~min}$ in this solution and subsequently resuspended in Alsever's solution. Cells were then stained by adding $100 \mu \mathrm{l}$ of Trypan Blue. After $30 \mathrm{~min}$, a drop of the solution was deposited on a glass slide and observed with VIDAS 2.1 image analysis system (Kontron, Munich, Germany). The longest diameter of cytoplasm and nucleus of 405 individual hemocytes was measured.

Statistical analysis. Differences in dimensions among hemocyte types were analyzed by ANOVA followed by Duncan tests for multiple comparisons (SOLO 2.0, BMDP Statistical Sofware Inc.).

Transmission electron microscopy (TEM). HemoIymph of 5 mussels was pooled for this assay. Hemolymph of each mussel was withdrawn $(1: 1)$ in fixative solution $\left(5 \%\right.$ glutaraldehyde in $0.1 \mathrm{M}$ piperazine- $N, N^{*}$ bis-[2-ethanesulfonic acid] (PIPES), $\mathrm{pH}=7.2$ with $7 \%$ sucrose). After $1 \mathrm{~h}$ at $4^{\circ} \mathrm{C}$ in fixative, cells were pelleted $(750 \times 9,10 \mathrm{~min})$, washed in buffer and postfixed in $1 \%$ osmium tetroxide ( $75 \mathrm{~min}$ at $4^{\circ} \mathrm{C}$ ). After washing, pellets were pre-embedded in $1.5 \%$ agar at $40^{\circ} \mathrm{C}$ and spun $(1700 \times g, 5 \mathrm{~min})$. Small pieces were cut, dehydrated through graded ethanol solutions, transferred into propylene oxide and finally embedded in Epon resin. Ultrathin sections (50 to $70 \mathrm{~nm}$ ) were cut and tissues contrasted with aqueous uranyl acetate and lead citrate and observed under a JEOL 100 CXII transmission electron microscope operating at $60 \mathrm{kV}$. 
Separation of hemocyte types by isopycnic centrifugation. Blood was obtained and simultaneously diluted (1:1) in Alsever's solution containing $6 \%$ formalin. Hemolymph of 15 mussels was pooled to obtain a suspension with ca $40 \times 10^{6}$ cells. After washing twice in Alsever's solution, hemocytes were separated by isopycnic centrifugation in discontinuous density gradient of Percoll (Noël et al. 1993). Cells concentrated at each interface were collected separately with a syringe. Cell suspensions from each interface were washed twice in Alsever's solution to remove Percoll. Pellets were resuspended in Alsever's solution and the number of hemocytes was then determined using a Malassez hemocytomer. Cytospin smears of $3 \times 10^{4}$ cells were prepared and stained with hemacolor.

Immunocharacterization. Four different monoclonal antibodies specific for hemocytes of Mytilus edulis were used. The antibodies were supplied by Dr Danielle Noël (Noël et al. 1991). Hemolymph of 5 mussels was withdrawn $(1: 1)$ in Alsever's solution containing $6 \%$ formalin. Hemocytes were pooled and centrifuged to remove formalin. The pellets were resuspended in Alsever's solution and cytospin smears of $3 \times 10^{4}$ cells were prepared. The immunoassays were also carried out on cytospin smears of hemocytes separated in gradients of Percoll. Both types of cytospin smears were fixed in acetone for $5 \mathrm{~min}$, washed in distilled water and used immediately or stored at $-20^{\circ} \mathrm{C}$ for 1 or 2 mo.

Indirect immunofluorescence assays and indirect immunoperoxidase assays were made following the procedure described by Noël et al. $(1993,1994)$. The percentage of green fluorescent reactive cells was determined in 5 random microscopic fields at $400 \times$ in the immunofluorescence assays. The percentage of brown reactive cells was determined in 20 microscopic fields at $1000 \times$ in the immunoperoxidase assays.

\section{RESULTS}

\section{Hemolymph cell types-light microscopy}

Two types of hemocytes were identified in stained spontaneous monolayers: hyalinocytes and granulocytes (Fig. 1). The hyalinocytes were less abundant and had a limited ability to spread on glass slides, thus showing a round shape. Their nucleus/cytoplasm (N/C) ratios were high. The basophilic cytoplasm, generally, did not contain granules. The cytoplasm of granulocytes showed less basophilia and spread more than the cytoplasm of hyalinocytes on glass slides. Ectoplasm and endoplasm were easily distinguished. The lucent ectoplasm presented numerous thin pseudopodia whereas endoplasm was more dense and con-
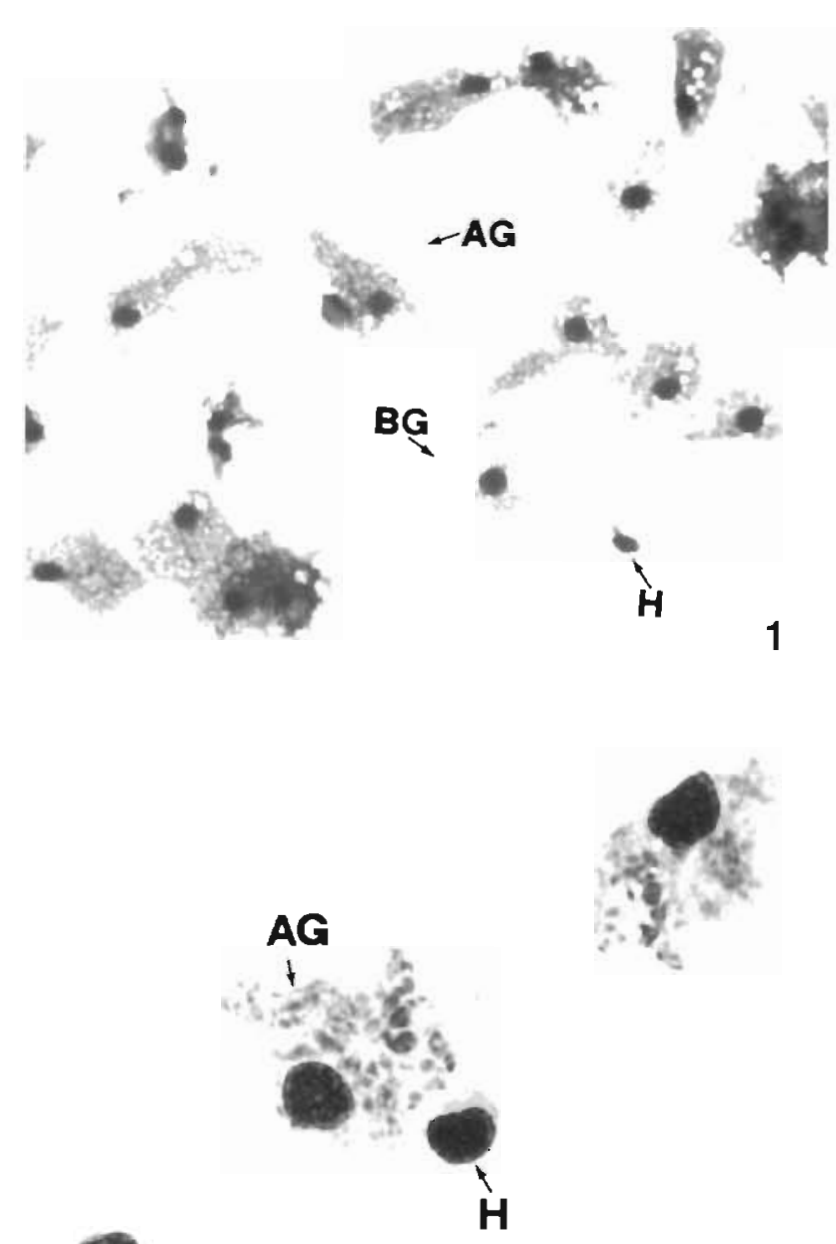

2

Figs, 1 \& 2. Mytilus galloprovincialis. Fig. 1. Hemocytes, allowed to settle for $30 \mathrm{~min}$ onto a glass slide (spontaneous monolayer) May-Grünwald-Giemsa stain, $\times 425$. Fig. 2. Cytospin smear of hemocytes. Hemacolor stain, $\times 1600$. AG: acidophilic granulocyte; BG: basophilic granulocyte; $\mathrm{H}$ : hyalinocyte

tained granules. Some granulocytes presented abundant acidophilic granules (acidophilic granulocytes, AG), others had only basophilic granules (basophilic granulocytes, BG) and a few of them contained both types of granules (BAG).

Hyalinocytes and granulocytes were also distinguished in stained cytospin smears (Fig. 2). Hyalinocytes were smaller than granulocytes and had large nuclei and reduced basophilic cytoplasm, generally without granules. However, some hyalinocytes contained small basophilic granules. Exceptionally, small hyalinocyte-like cells with acidophilic granules were observed. Granulocytes were larger than hyalinocytes 
and could be classified according to the staining properties of their cytoplasmic granules in the same way as in spontaneous monolayers. Some BGs contained very few granules. BAGs generally showed more acidophilic than basophilic granules.

Some granulocytes contained refringent orange inclusions larger than cytoplasmic granules. Large multinucleate granulocytes were also observed in a single monolayer of hemocytes. In addition, cells with yellowbrown granules were seen on several slides. Around $1.5 \%$ of the hemocytes (both hyalinocytes and granulocytes) showed 2 nuclei.

\section{Hemocyte dimensions}

Hemocyte dimensions measured in spontaneous monolayers are shown in Table 1 . Differences among cell types were found to be significant $(p<0.001)$ for cell size, nucleus diameter and $\mathrm{N} / \mathrm{C}$ ratio by means of ANOVA. Nevertheless, differences in nucleus diameter and N/C ratio between BGs and BAGs were not significant.

Hyalinocytes appeared as the smallest cells with the highest $\mathrm{N} / \mathrm{C}$ ratio and granulocytes as the largest cells with the lowest $\mathrm{N} / \mathrm{C}$ ratio.

Hemocytes fixed in suspension had a round shape. This technique permitted distinction between hyalinocytes and granulacytes, but it was not possible to detect different granulocyte types because all granules stained blue. Hemocyte dimensions measured with this technique are shown in Table 2. Differences in cell size, nucleus diameter and $\mathrm{N} / \mathrm{C}$ ratio between hyalinocytes and granulocytes were significant ( $p<$ $0.001 ; \mathrm{p}<0.05 ; \mathrm{p}<0.001$, respectively).

Table 1 Dimensions of Mytilus galloprovincialis hemocytes measured in a spontaneous monolayer. Mean values \pm standard error and rank of vanation corresponding to cell diameter, nucleus diameter and nucleus/cytoplasm ( $\mathrm{N} / \mathrm{C})$ ratio of each hemocyte type are shown. H: hyalinocyte BG: basophilic granulocyte; BAG: granulocyte with basophilic and acidophilic granules; AG: acidophilic granulocyte $N$ : number of measured cells

\begin{tabular}{|cccc|}
\hline Cell type & $\begin{array}{c}\text { Cell diameter } \\
(\mu \mathrm{m})\end{array}$ & $\begin{array}{c}\text { Nucleus } \\
\text { diameter }(\mu \mathrm{m})\end{array}$ & $\mathrm{N} / \mathrm{C}$ \\
\hline $\mathrm{H}(\mathrm{N}=26)$ & $8.73 \pm 0.54$ & $5.27 \pm 0.27$ & $0.62 \pm 0.01$ \\
& 5 to 17 & 3 to 8 & 0.83 to 0.44 \\
$\mathrm{BG}(\mathrm{N}=42)$ & $43.70 \pm 0.91$ & $7.71 \pm 0.12$ & $0.18 \pm 0.01$ \\
& 31 to 55 & 6 to 9 & 0.26 to 0.15 \\
$\mathrm{BAG}(\mathrm{N}=35)$ & $44.70 \pm 1.34$ & $7.54 \pm 0.13$ & $0.17 \pm 0.01$ \\
& 37 to 66 & 6 to 9 & 0.20 to 0.13 \\
$\mathrm{AG}(\mathrm{N}=71)$ & $4908 \pm 0.70$ & $6.83 \pm 0.09$ & $0.14 \pm 0.00$ \\
& 37 to 66 & 5 to 9 & 0.18 to 0.11 \\
& & &
\end{tabular}

Table 2. Dimensions of Mytilus galloprovincialis hemocytes measured in suspension. Mean \pm standard error and rank of variation corresponding to cell diameter, nucleus diameter and $\mathrm{N} / \mathrm{C}$ ratio of each hemocyte type are shown. $\mathrm{H}$ : hyalinocyte; G: granulocyte; $N$ : number of measured cells

\begin{tabular}{|lccc|}
\hline Cell type & $\begin{array}{c}\text { Cell diameter } \\
(\mu \mathrm{m})\end{array}$ & $\begin{array}{c}\text { Nucleus } \\
\text { diameter }(\mu \mathrm{m})\end{array}$ & $\mathrm{N} / \mathrm{C}$ \\
\hline $\mathrm{H}(\mathrm{N}=200)$ & $8.33 \pm 0.15$ & $5.05 \pm 0.10$ & $0.61 \pm 0.10$ \\
& 5.11 to 12.55 & 2.46 to 6.95 & 0.14 to 0.40 \\
$\mathrm{G}(\mathrm{N}=205)$ & $10.95 \pm 0.16$ & $4.76 \pm 0.10$ & $0.44 \pm 0.01$ \\
& 7.30 to 14.74 & 2.58 to 7.76 & 0.28 to 0.79 \\
\hline
\end{tabular}

\section{Electron microscopy}

Examination of the circulating hemocytes by electron microscopy revealed the occurrence of agranular (hyalinocytes) and granular (granulocytes) hemocytes.

The hyalinocytes appeared as rounded cells with large central nuclei, relatively small cytoplasm, and occasionally with some pseudopodia (Fig. 3). Their cytoplasm contained few organelles, some mitochondria, some cisternae and vesicles of rough and smooth endoplasmic reticulum and free ribosomes. Two types of nuclei were observed in the hyalinocytes. Some of them mostly contained euchromatin and others had large clumps of heterochromatin. Some hemocytes similar to hyalinocytes had a more developed cytoplasm containing long strands of smooth endoplasmic reticulum, numerous free ribosomes and a few small granules (Fig. 4). The nuclei of the latter frequently contained a nucleolus.

The granulocytes were more abundant than hyalinocytes. They were ovoid in shape, frequently showing thin pseudopodia, with an eccentric nucleus which contained abundant heterochromatin in the central and peripheral positions. The $\mathrm{N} / \mathrm{C}$ ratio was lower than in hyalinocytes, and cytoplasmic organelles were more abundant. Granulocytes had abundant mitochondria, cisternae and vesicles of rough and smooth endoplasmic reticulum and Golgi complex. In addition, they contained membrane-limited granules with variable electron-dense content. Most of these granules were round or oval in shape and presented a central electron-dense content rounded by an electron-lucent halo. The diameter of the granules ranged from 0.2 to $1.8 \mu \mathrm{m}$. Some granulocytes contained only small granules (diameter $<0.5 \mu \mathrm{m}$ ) (Fig. 5); others had abundant large granules (diameter $>0.5 \mu \mathrm{m}$ ) (Fig. 6) and some of them showed a mix of granule sizes (Fig 7). Cells containing small granules had more abundant mitochondria and long strands of rough endoplasmic reticulum around the nucleus. The cytoplasm of cells containing large granules frequently presented vacuoles which 

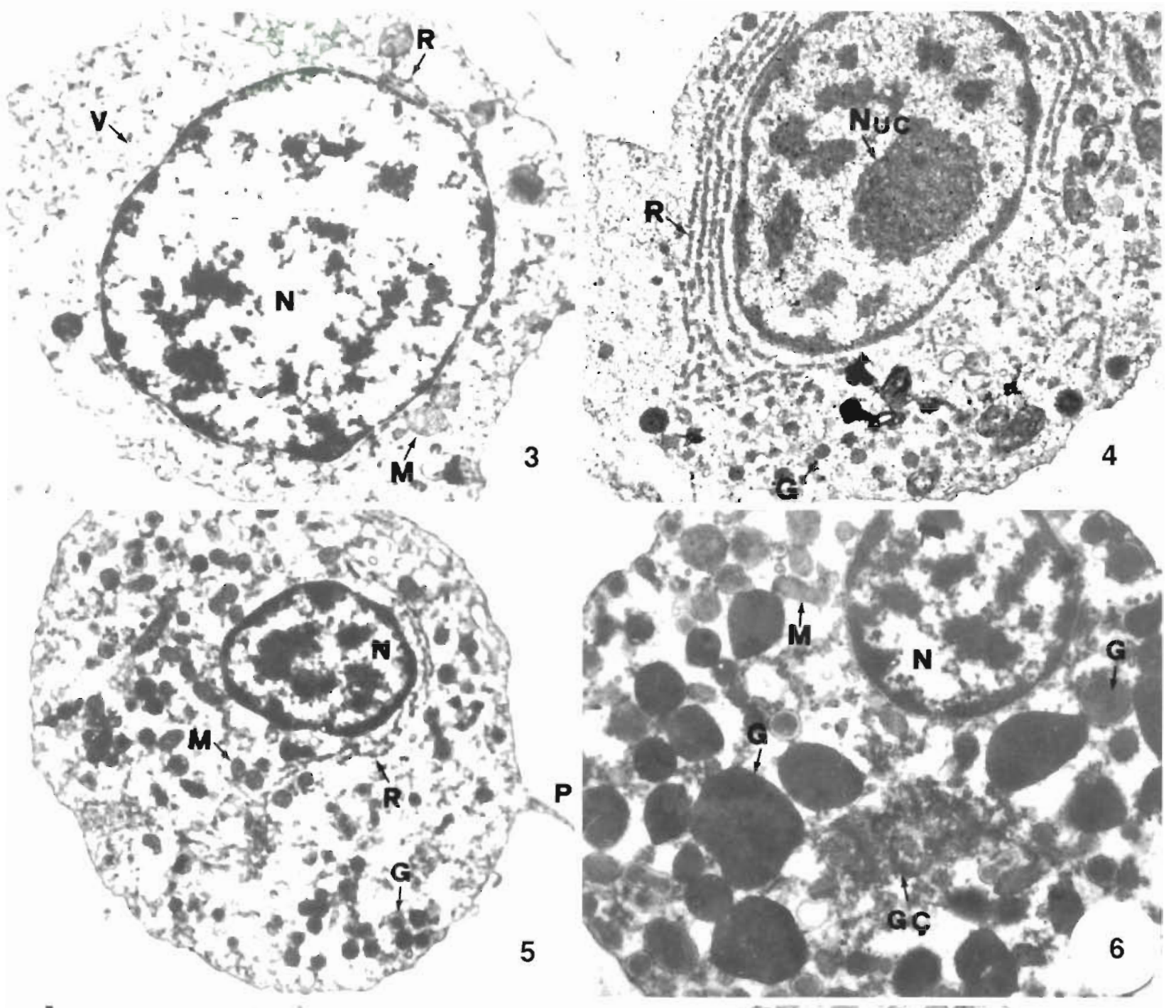

1
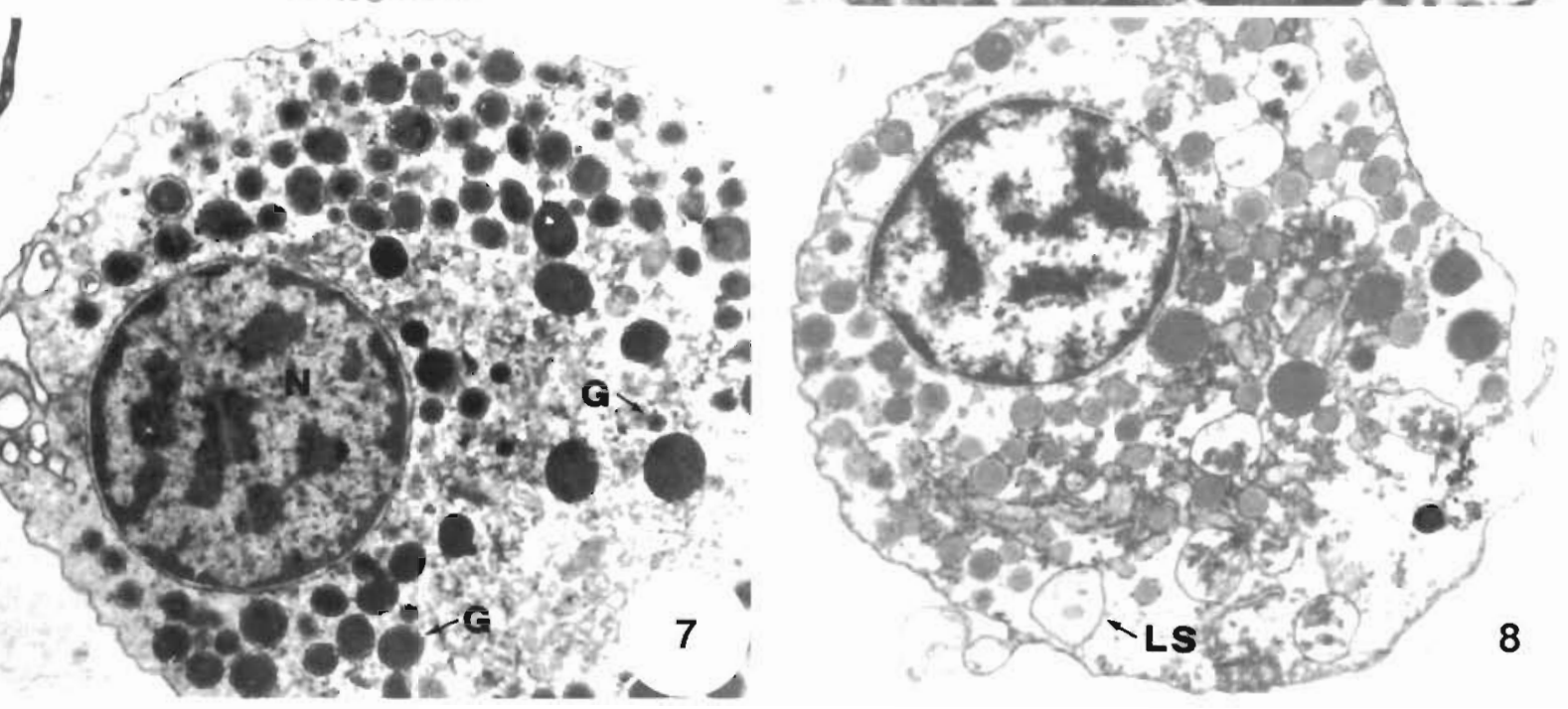

Figs. 3 to 8. Mytilus galloprovincialis. Fig 3 Hyalnocyte with a nucleus contannng abundant euchromatm $M$ mitochondrion, N: nucleus; R: rough endoplasmic retıculum; V. vacuole. Transmission electron microscopy (TEM), $\times 7500$. Fig. 4. Hemocyte similar to hyalinocytes, whose cytoplasm contains long strands of rough endoplasmic retıculum, abundant free ribosomes and a few small granules (G). Nuc: nucleolus. TEM, $\times 8000$. Fig 5 Granulocyte containing small granules P. pseudopod. TEM, $\times 7500$. Fig. 6. Granulocyte containing large granules GC Golg1 complex TEM, $\times 7500$ Fig. 7 Granulocyte contanning a mix of granule sizes. TEM, $\times 8000$. Fig. 8. Granulocyte containing secondary lysosomes (LS). TEM, $\times 7000$ 
included different materials. Some of these vacuoles were secondary lysosomes and residual bodies (Fig. 8)

\section{Separation of hemocyte types by isopycnic centrifugation}

The hemocyte suspensions were separated into 5 fractions by centrifugation in discontinuous Percoll gradient. The different fractions were formed at the interfaces $10-20 \%, 20-30 \%, 30-40 \%$ and $40-50 \%$ of Percoll and in the pellet. Microscopic examination of different fractions showed that the number of hyalinocytes and BGs was lower in the interfaces containing a higher percentage of Percoll. However, the number of AGs increased with the density gradient, so that the pellet only contained AGs (Table 3).

Table 3. Percentages of hemocyte types collected at interfaces

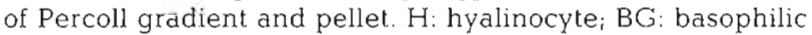
granulocyte; BAG: granulocyte with acidophilic and basophilic granules; AG: acidophilic granulocyte

\begin{tabular}{|lcccc|}
\hline Fraction & $\mathrm{H}(\%)$ & $\mathrm{BG}(\%)$ & $\mathrm{BAG}(\%)$ & $\mathrm{AG}(\%)$ \\
\hline $10-20 \%$ & 29 & 66 & 5 & 0 \\
$20-30 \%$ & 14 & 76.5 & 8 & 1.5 \\
$30-40 \%$ & 4 & 41 & 21.5 & 33.5 \\
$40-50 \%$ & 0 & 1.5 & 1 & 97.5 \\
$>50 \%$ (pellet) & 0 & 0 & 0 & 100 \\
\hline
\end{tabular}

\section{Immunocharacterization with monoclonal antibody}

Immunofluorescence assays showed that all monoclonal antibodies specific for Mytilus edulis hemocytes reacted with $M$. galloprovincialis hemocytes. The 11 A1-3F9 and 20 D3-3B4 antibodies gave rise to the most intense reactions (Table 4 ).

The immunoperoxidase staining permitted an easier distinction among hemocyte types than immunofluorescence staining. Using this technique, the 13 B9-2E6 antibody showed reaction in the cytoplasm of BGs but

Table 4. Immunofluorescence staining of Mytilus galloprovincialis hemocytes with monoclonal antibodies ralsed against $M$. edulis hemocytes. +: weak staining +++ : very strong staining

\begin{tabular}{lcc} 
Antibody & Reactive hemocytes (\%) & Intensity of reaction \\
\hline $11 \mathrm{~A} 1-3 \mathrm{~F} 9$ & 99 & +++ \\
$13 \mathrm{~B} 9-2 \mathrm{E} 6$ & 55 & +++ \\
$20 \mathrm{D} 3-3 \mathrm{~B} 4$ & 79 & +++ \\
$18 \mathrm{C} 5-3 \mathrm{H} 10$ & 51.9 & +
\end{tabular}

not AGs. The remaining antibodies recognized both types of granulocytes. Few hyalinocytes showed reaction with 20 D3-3B4, 18 C5-3H10 and 11 Al-3F9 antibodies. A higher number of $A G$ s reacted than did $B G$ s, mainly with 20 D3-3B4 and 18 C5-2E6 antibodies. It was impossible to distinguish BAGs clearly using this technique.

\section{Reactivity of hemocytes separated by isopycnic centrifugation in Percoll with 13 B9-2E6 monoclonal antibody}

Immunofluorescence assays were carried out with this antibody and the hemocytes of 5 fractions obtained by density gradient centrifugation. The highest number of reactive cells was observed at the 20 to $30 \%$ interface, where BGs were more abundant (Table 5). The number of reactive cells decreased progressively through the increasing density gradient. No reaction was detected in the pellet which only contained AGs.

Table 5. Immunofluorescence staining of Mytilus galloprovincialis hemocytes separated in Percoll gradient using 13 B9-2E6 monoclonal antibody

\begin{tabular}{|cc|}
\hline Fraction & Reactive hemocytes $(\%)$ \\
\hline $10-20 \%$ & 24.64 \\
$20-30 \%$ & 49.25 \\
$30-40 \%$ & 21.21 \\
$40-50 \%$ & 2.78 \\
$>50 \%$ & 0 \\
\hline
\end{tabular}

\section{DISCUSSION}

The results of this study reveal the occurrence of 2 hemocyte types in the hemolymph of Mytilus galloprovincialis: hyalinocytes and granulocytes. The hyalinocytes are agranular cells and present a central large nucleus surrounded by relatively small cytoplasm. The granulocytes are larger cells with a smaller nucleus and cytoplasmic granules. Moreover, they are more able to spread and produce pseudopodia. AGs, $B G$ and $B A G$ s can be distinguished according to the staining properties of their granules. The $B G$ s are smaller with larger nuclei than AGs. The BAGs have intermediate sizes.

The results of isopycnic centrifugation showed that hemocytes can be separated by their density. The hyalinocytes and BGs have a lower density than AGs. The latter can be obtained in a pure fraction. Therefore, AGs are the cells with the largest size and the highest density in the mussel hemolymph. 
Cells containing yellow-brown granules were also observed in hemocyte monolayers. These cells have been described in other bivalves as brown cells, which have an excretory role (Cheng 1981). Also, the cytoplasm of some granulocytes presented orange inclusions larger than granules. These inclusions are probably phagosomes containing degradation products. In addition, multinucleate giant hemocytes were found on one slide from a mussel heavily infested by a trematode, Proctoeces maculatus. These cells have been observed in other molluscs (Sparks \& Pauley 1964, Cheng 1984, Auffret 1985). They are considered to be the result of a fusion of granulocytes in some pathological conditions such as postmortem changes or rejection of grafts.

At the ultrastructural level, the hyalinocytes present characteristics of undifferentiated cells: a small volume of cytoplasm that contains few organelles, abundant free ribosomes and a nucleus with abundant euchromatin. The granulocytes are more differentiated cells and can be classified according to the size of granules. The granulocytes with small granules have more mitochondria and a well-developed rough endoplasmic reticulum. The granulocytes with large granules show scant rough endoplasmic reticulum and frequently contain secondary lysosomes and residual bodies as a result of their important phagocytic activity (authors' unpubl. data). This last characteristic indicates that they are the most mature cells (Klebanoff et al. 1978)

On the basis of morphological criteria, several authors distinguished granulocyte subpopulations in Mytilus edulis and $M$. californianus (Feng 1977, Moore \& Lowe 1977, Bayne et al. 1979, Rasmussen et al. 1985. Renwrantz 1990). Pipe (1990b) separated the granulocytes of the mussel $M$. edulis in granulocytes with small granules (0.2 to $0.3 \mu \mathrm{m}$ diameter) and granulocytes with large granules (0.5 to $1.5 \mu \mathrm{m}$ diameter) and did not find clear intermediary types. Noël et al. (1994) demonstrated that the basophilic granulocytes of $M$. edulis observed by light microscopy correspond to the granulocytes with small granules and the acidophilic granulocytes correspond to the granulocytes with large granules. Rasmussen et al. (1985) suggested that small $M$. edulis granulocytes become larger granulocytes with larger granules through maturation. The presence of granulocytes containing a mix of granule sizes in $M$. galloprovincialis seems to support this hypothesis. Nevertheless, it could also be possible that the granulocytes containing a mix of granules are larger granulocytes synthesizing new granules or a functionally different granulocyte subpopulation.

Monoclonal antibodies have been used for antigenic characterization of the bivalve hemocytes in the case of Crassostrea gigas (Morvan 1991) and Mytilus edulis (Noël et al. 1991, 1994). Noël et al. (1994) demon- strated that monoclonal antibodies specific for $M$ edulis hemocytes showed immunofluorescent staining with $M$. galloprovincialis, $M$. trossulus and $M$. californianus hemocytes. Our results are very similar to those obtained by Noël, with small differences in the percentage of reactive cells. These differences are probably caused by different proportions of cell types on the slides.

The results of immunoperoxidase assays suggest that the $13 \mathrm{~B} 9-2 \mathrm{E} 6$ monoclonal antibody is specific for BGs. When this monoclonal antibody was assayed with the hemocytes separated through density gradient, the highest number of rective cells was found in the fraction containing the highest number of BGs. Furthermore, the reaction decreases as the proportion of BGs decreases. The results of these 2 assays demonstrate that Mytilus galloprovincialis hemocytes are an antigenically heterogeneous population. Similar results were obtained in $M$. edulis hemocytes (Noël et al. 1994) with the 13 B9-2F8 monoclonal antibody. However, in our case, some hyalinocytes showed reaction with the 20 D3-3B4, $18 \mathrm{C} 5-3 \mathrm{H} 10$, and $11 \mathrm{~A} 1-3 \mathrm{~F} 9$ monoclonal antibodies, whereas Noël et al. (1994) did not observe any reaction in $M$. edulis hyalinocytes with these 3 antibodies. Therefore, antigenic differences between hyalinocytes and granulocytes observed in $M$. edulis could be considered less important in $M$. galloprovincialis.

Cheng (1981) suggested that AGs are the most mature cells and are probably originated from BGs. Some Mytilus galloprovincialis granulocytes presented intermediate morphological characteristics (cell size, granular size, staining properties of granules), thus suggesting a maturation process. The fact that $13 \mathrm{~B} 9$ $2 \mathrm{E} 6$ monoclonal antibody is specific for BGs might lead to a different conclusion. However, as stated by Noël et al. (1994), it is possible that the epitope recognized by this antibody is manifested early and disappears rapidly in the maturation process.

There are several theories on bivalve hemocyte renewal and maturation. Moore \& Eble (1977) suggested that different hemocyte types are maturing stages within a single cell line. Cheng (1981) proposed an ontogenic model with 2 cell lines, one for hyalinocytes and another for granulocytes, each originating from a different prohemocyte. Auffret (1988) also suggested this last hypothesis for Ostrea edulis and Crassostrea gigas hemocytes. Our results do not allow us to confirm any of the previous hypotheses, since the morphological variability found by light and electron microscopy in Mytilus galloprovincialis hemocytes could be alternatively explained as transition stages of a single cell line or stages belonging to different cell lines. Further studies are needed to understand bivalve hemopoiesis. 
The ultrastructural study of Mytilus galloprovincialis hemocytes showed that some hyalinocytes contain a nucleus with abundant euchromatin and others have a nucleus with large clumps of heterochromatin. Both types of hyalinocytes could belong to a different cell line, one for hyalinocytes and another for granulocytes. Another possibility is that the hyalinocytes containing abundant euchromatin give rise to hyalinocytes with more heterochromatin and granulocytes. Also, some hemocytes similar to hyalinocytes had a more developed cytoplasm containing long strands of rough endoplasmic reticulum, numerous free ribosomes and some small granules. These cells are probably intermediate forms that give rise to granulocytes, since they seem to have an important role in protein synthesis and the granules contain abundant enzymes (authors' unpubl. results)

Some granulocytes with 2 nuclei were found in hemocyte monolayers. This may indicate that granulocytes have a separate origin from hyalinocytes. Moore \& Lowe (1977) also observed Mytilus edulis granulocytes containing 2 nuclei and suggested that there can be a nuclear replication without cell division.

In conclusion, results of our study show similarities between hemocytes of Mytilus galloprovincialis and $M$. edulis. Nevertheless, some new aspects with regard to previous studies on $M$. edulis hemocytes were uncovered. The occurrence of multinucleate giant hemocytes, circulating brown cells, and binucleate hyalinocytes was not previously reported. At the ultrastuctural level, 2 nucleus types were observed among the hyalinocytes, one of them mostly contained euchromatin and the other with abundant heterochromatin. Granulocytes with similar proportion of large and small cytoplasmic granules were found. Some of the monoclonal antibodies reacting with granulocytes also showed reaction with some hyalinocytes.

Acknowledgememts. We are grateful to Dr Danielle Noël for supplying the monoclonal antibodies against Mytilus edulis hemocytes, to Ms Laura Corral, who provided technical assistance with ultrastructural studies, and Dr José Molares for his technical assistance with image analysis equipment. The mussel farmer Mr Luis Losada supplied the mussels for this study.

\section{LITERATURE CITED}

Adema CM, Mohandas A, Van der Knaap WPW, Sminia I (1994) Separation of Lymnaea stagnalis hemocytes by density gradient centritugation. Dev Comp Immunol 18 : 25-31

Auffret M (1985) Morphologie comparative des types hémocytaries chez quelques mollusques bivalves d'intérêt commercial. Thèse de doctorat, Université de Bretagne Occldentale, Brest
Auffret M (1988) Bivalve hemocyte morphology. Am Fish Soc Spec Publ 18:169-177

Auffret M (1989) Comparative study of the hemocytes of two oyster species: the European flat oyster, Ostred edulis, Linnaeus, 1750 and the Pacific oyster, Crassostrea gigas (Thunberg, 1793) J Shellfish Res 2:367-373

Bachère E, Chagot D. Grizel H (1988) Separation of Crassostrea gigas hemocytes by density gradient centrifugation and counterflow centrifugal elutriation. Dev Comp Immunol 12:549-559

Bayne CJ, Moore MN, Carefoot TH, Thompson RJ (1979) Hemolymph functions in Mytilus californianus: the cytochemistry of hemocytes and their responses to foreign implants and hemolymph factors in phagocytosis. J Invertebr Pathol 34:1-20

Cheng TC (1981) Bivalves. In: Ratcliffe NA, Rowley AF (eds) Invertebrate blood cells, Vol II. Academic Press, London, p 231-300

Cheng TC (1984) A classification of molluscan hemocytes based on functional evidences. In: Cheng TC (ed) Comparative pathobiology, Vol 6. Invertebrate blood cells and serum factors. Plenum, New York, p 111-146

Cheng TC, Huang JW, Karadogan H, Renwrantz LR, Yoshino $\Upsilon$ (1980) Separation of oyster hemocytes by density gradient centrifugation and identification of their surface receptors. J Invertebr Pathol 36:35-40

Cousteau C, Renaud F, Maillard C, Pasteur N, Delay B (1991) Differential susceptibility to a trematode parasite among genotypes of the Mytilus edulis/galloprovincialis complex. Genet Res Camb 57:207-212

Crespo CA, García Caballero T, Beiras A, Espinosa J (1990) Evidence from sperm ultrastructure that the mussel of Galician estuaris is Mytilus galloprovincialis Lamark. J Mollusc Stud 56:127-1.28

Dikkeboom R, Tijnagel JMGH. Mulder EC, Van der Knaap WPW (1987) Monoclonal antibody recognized hemocyte subpopulations in juvenile and adult Lymnaea stagnalis: functional characteristics and lectin binding. Dev Comp Immunol 12:17-32

Dikkeboom R, Tijnagel JMGH, Van der Knaap WPW (1988) Monoclonal antibody recognized hemocyte subpopulations in juvenile and adult Lymnaed stagnalis: functional characteristics and lectin binding. Dev Comp Immunol 12:17-32

Dikkeboom R, Van der Knaap WPW, Maaskant JJ, De Jonge AJ (1985) Different subpopulations of hemocytes in juvenile, adult and Trichobilharzia ocellata-infected Lymnaea stagnalis: a characterization usıng monoclonal antibodıes. Z Parasitenkd 71:815-819

Feng SY, Feng JS, Yamasu T (1977) Roles of Mythlus coruscus and Crassostrea gigas blood cells in defense and nutrition. In: Bulla LA Jr, Cheng TC (eds) Comparative pathobiology, Vol 3. Plenum, London, p 31-67

Fisher WS (1986) Structure and function of oyster hemocytes. In: Brehelin $M$ (ed) Immunity in invertebrates. SpringerVerlag, Berlin, p 25-35

Ford SE, Ashton-Alcox KA, Kanaley SA (1994) Comparative cytometric and microscopic analysis of oyster hemocytes. J Invertebr Pathol 64:114-122

Gardner JPA (1992) Mytilus galloprovincialis (Lmk) (Bivalvia, Mollusca): the taxonomic status of the Mediterranean mussel. Ophelia 35 (3): 219-243

Gardner JPA (1995) Developmental stability is not disrupted by extensive hybridization and introgression among populations of the marine bivalve molluscs Mytilus edulis (L.) and M. galloprovincialis (Lmk.) from south-west England. Bıol J Linn Soc 54:71-86 
Gardner JPA (1996) The Mytilus edulis species complex in southwest England: effects of hybridization and introgression upon interlocus associations and morphometric variation. Mar Biol 125:385-399

Gardner JPA, Skibinski DOF (1990) Genotype-dependent fecundity and temporal variation of spawning in hybrid mussel (Mytilus) population. Mar Biol 105:153-162

Gardner JPA, Skibinski DOF (1991) Biological and physical factors influencing genotype-dependent mortality in hybrid mussel populations. Mar Ecol Prog Ser 71:235-243

Gardner JPA, Skibinski DOF, Bajdik CD (1993) Shell growth and viability differences between the marine mussels Mytilus edulis (L.), Mytilus galloprovincialis (Lmk.), and their hybrids from two sympatric populations in S.W. England. Biol Bull 185:405-416

Gosling EM (1992) Genetics of Mytilus. In: Gosling E (ed) The mussel Mytilus: ecology, physiology, genetics and culture. Developments in aquaculture and fisheries science, Vol 25. Elsevier, Amsterdam, p 309-382

Hilbish TJ, Bayne BL, Day A (1994) Genetics of physiological differentiation within the marine mussel genus Mytilus. Evolution 48(2): 267-286

Holden JA, Pipe RK, Quaglia A, Ciani G (1994) Blood cells of the arcid clam Scapharca inaequivalvis. J Mar Biol Assoc UK 74:287-299

Klebanoff SJ, Clark RA (1978) The neutrophil: function and clinical disorders. North-Holland Biomedical Press/Elsevier, Amsterdam

Koëhn RK (1991) The genetics and taxonomy of species in the genus Mytilus. Aquaculture 94:125-145

Martínez-Lage A, Insua A, Martinez Exposito MJ, Mendez J (1992) Estudio comparativo entre una población de mejillón gallego y otra de mejillón mediterraneo. Seminario Internacional do Mexillón, Cuadernos da Area de Ciencias Mariñas, Vol 6. Seminario de Estudos Galegos (ed), Ediciós do Castro, Sada, p 57-63

MCDonald JH, Seed R, Koehn RK (1991) Allozyme and morphometric characters of three species of Mytilus in the Northern and Southern hemispheres. Mar Biol 111. 323-335

Moore CA, Eble AF (1977) Cytochemical aspects of Mercenaria mercenaria hemocytes. Biol Bull 152:105-119

Moore MN, Lowe DM (1977) The cytology and the cytochemistry of the hemocytes of Mytilus edulis and their reponses to experimentally injected particles. J Invertebi Pathol 29: $18-30$

Morvan A (1991) Caractérisation antigénique des hémocytes de l'huitre Crassostrea gigas et analyse de leur activité anti-infectieuse oxygène-dépendante Rapport de D.E.A., Université de Bordeaux II

Noël D, Bachere E, Mialhe E (1993) Phagocytosis associated chemiluminescence of hemocyte in Mytilus edulis (Bivalvia). Dev Comp Immunol 17:483-493

Responsible Subject Editor: A. K. Sparks, Seattle, Washington, USA
Noël D, Boulo V, Chagot D, Mialhe E (1991) Preparation and characterization of monoclonal antibodies against neoplastic hemocytes of Mytilus edulis. Dis Aquat Org 10: $51-58$

Noël D, Pipe R, Elston R. Bachere E, Mialhe E (1994) Antigenic characterization of hemocyte subpopulations in the mussel Mytilus edulis by means of monoclonal antibodies. Mar Biol 119:549-556

Pipe RK (1990a) Hydrolytic enzymes associated with the granular haemocytes of the marine mussel Mytilus edulis. Histochem J 22:595-603

Pipe RK (1990b) Differential bindıng of lectins to haemocytes of the mussel Mytilus edulis. Cell Tissue Res 261:261-268

Quesada H, Zapata C, Alvarez G (1995) A multilocus allozyme discontinuity in the mussel Mytilus galloprovincialis: the interaction of ecological and life-history factors. Mar Ecol Prog Ser 116:99-115

Rasmussen LPD, Hage E, Karlog O (1985) An electron microscope study of the circulating leucocytes of the marine mussel Mytilus edulis. J Invertebr Pathol 45:158-167

Renwrantz L (1990) Internal defence system of Mytilus edulis. In: Stefano GB (ed) Neurobiology of Mytilus edulis. Manchester University Press, Manchester, p 256-275

Russell-Pinto F, Reimao R, De Sousa M (1994) Haemocytes in Cerastoderma edule (Mollusca Bivalvia): distinct cell types engage in different responses to sheep erythrocytes. Fish Shellfish Immunol 4:383-397

Sanjuán A, Comesaña A.S, De Carlos A (1996) Macrogeographic differentation by mtDNA restriction site analysis in the SW. European Mytilus galloprovincialis Lmk. J Exp Mar Biol Ecol 198:89-100

Sanjuán A, Quesada H, Zapata C, Alvarez G (1990) On the occurrence of Mytilus galloprovincialis Lmk on the NW coast of the Iberian Peninsula. J Exp Mar Biol Ecol 143 . $1-14$

Sanjuán A, Zapata C, Alvarez C (1994) Mytilus galloprowncialis and $M$. edulis on the coasts of the Iberian Peninsula. Mar Ecol Prog Ser 113:131-146

Sparks AK, Pauley GB (1964) Studies of normal postmorten changes in the oyster, Crassostrea gigas (Thunberg). J Insect Pathol 6:78-101

Willis GL, Skibinski DOF (1992) Variation in strength of attachment to the substrate explains differential mortality in hybrid mussel (Mytilus galloprovincialis and $M$. edulis) populations. Mar Biol 112:403-408

Yoshino TP, Granath WO Jr (1983) Identification of antigenically distinct hemocyte subpopulations in Biomphalaria glabrata (Gastropoda) using monoclonal antibodies to surface membrane markers. Cell Tisssue Res 232:553-564

Yoshino TP, Granath WO Jr (1985) Surface antigens of Biomphalaria glabrata (Gastropoda) hemocytes: functional heterogeneity in cell subpopulations recognized by a monoclonal antibody. J Invertebr Pathol 45:174-186

Manuscript first received: April 26, 1996

Revised version accepted: January 15, 1997 